\title{
From South to North in the Globalised World of Early Childhood Education and Care: Varied national and local responses in selected countries
}

\author{
Branislav Pupala, Ondrej KašČák
}

\begin{abstract}
This article analyses the neoliberal transformation of ECEC in five selected countries (Germany, Slovakia, Indonesia, Nepal, and Kenya). Both the Global South and the Global North are represented. The countries were selected either because of the authors' involvement in research in the respective country or because of their long-term personal experience of that particular system of ECEC. The knowledge the authors acquired enabled them to delve deeper into the question of the point at which ECEC systems encounter neoliberal education policy and to describe the different ways in which the countries have adapted to the new policies. The article shows that neoliberal education policies require different types of adaptation and that these may have very different effects on the system of ECEC - from a change in concept to system convergence and practical resistance or total governance of the ECEC sector. The article contributes to a more granular understanding of the effect of the economising discourse on the ECEC sector.
\end{abstract}

Keywords: ECEC, social investment approach, EU, Germany, Slovakia, Indonesia, Kenya, Nepal, Global North, Global South

\section{INTRODUCTION}

ECEC is currently attracting major interest in education policies across the world. This can be seen as an opportunity to develop the preschool sector, build capacity, and improve the quality of education services and staff. Efforts are being made across the world to further develop the institutional basis of ECEC, to raise children's preschool participation levels to varying degrees, to professionalise this segment of childcare, and to further public debate on ECEC issues. At the same time, however, critical voices suggest that policy interests may not coincide with the interests of the child.

There are many countries where there is no tradition of the institutional provision of ECEC and where the required infrastructure is only just beginning to be put in place, while other countries not 
only have a well-developed infrastructure but also have long-standing experience of and have debated the various philosophies, principles, and ideals of ECEC.

In global terms, this convergence began only recently, despite the gradual shift in the direction of ECEC education policy and it becoming linked with the activities of the OECD over the last twenty years at least. Of late there has been strong reliance on the need to analyse the economic costs and benefits of the various forms and levels of education. This has led to the creation of institutions and to the strengthening of capacity in the economics of education. At the European Union level, this has been seen in support for the European Expert Network on the Economics of Education (Jones, 2010), whose activities are linked to the strategy for the economic competitiveness of Europe (the Lisbon Strategy). The reports produced by this expert group and other groups set up in developed countries primarily indicate that the ECEC sector has come to be seen as the sector with the greatest societal return on investment. This has led to it receiving attention in education policy, and over the last ten years it has regularly appeared in important strategic education documents. The ECEC sector has come to the forefront of education policies because of its added economic value.

One can argue that ECEC is predominantly viewed as a "social investment", capable of providing economic benefits for society and financial benefits for the individual (Nicaise \& Schepers, 2013). According to Casalini (2014) this per- spective is not only driving the European view of ECEC but is also pushing back against the alternative, traditional perspective that prioritises children's rights. This is despite the knowledge that this perspective is very important in poorer countries and in developing countries around the world. Globally, then, there is an ongoing shift in the emphasis on the importance and function of ECEC. In education policy this shift is occurring in the form of three tendencies: greater state control of ECEC institutions, especially through assessments of quality and standard, the global revision and homogenisation of ECEC curricula, and stronger ties between ECEC institutions and the education sector ("schoolification").

In this study we will look at some examples of the transformation of ECEC in selected countries, as shaped by this new global, economising view of ECEC. The examples all come from countries where we have been part of collaborative research teams or from countries where over the years we have built up a personal familiarity with the ECEC systems in place. The selection comprises two European (developed) countries as well as some developing countries. In other words it includes countries in the Global North as well as in the Global South.

These countries were not randomly selected but chosen because they reflect the geographical distribution of the authors' research interests and form part of their collaborative network of comparative ECEC researchers. The two geopolitical units (Global North and Global South) 
are represented by states in which the authors have studied early childhood care and preschool education and gathered the generalised information presented here. That information has been verified through direct comparisons, discussions and collaboration with local actors, and by contrasting it with knowledge of the overall cultural context of these countries.

\section{EUROPEAN SHIFTS}

The European Union's unequivocal move towards an economising view of preschool education was set out in a Commission communication entitled Early Childhood Education and Care: Providing all our children with the best start for the world of tomorrow (European Commission, 2011). It accepts the OECD's position that general education should foster the competencies essential for competing on the labour market. The OECD described these competencies via its concept of literacy in language, mathematics, and natural science, as tested in the PISA assessments. Many EU countries had already failed to achieve satisfactory results in the first round of the assessments and so measures to improve student performance had already been the subject of discussion within the EU for some years. Therefore, in the Commission's communication the strongest arguments for supporting and reforming ECEC came from expert economic analyses and existing analyses of the importance of early years learning in improving education results further up the education system.
The link between early years education and later educational outcomes is expressed clearly in the Communication: "There is clear evidence that participation in high-quality ECEC leads to significantly better attainment in international tests on basic skills, such as PISA and PIRLS, equivalent to between one and two school years of progress." (European Commission, 2011, p. 1)

Consequently, the link between school education and curricula became an important theme in European debates. All this was aimed at ensuring better student education pathways and an improved ability to compete on the labour market, and was to be achieved mainly through academic success in the core areas of the knowledge economy (language, mathematics, technical thinking, natural science), which was exactly what the EU's Lisbon Strategy sought to boost.

\section{A change in conception - Germany}

Germany was one of the first EU countries to begin changing direction. The catalyst for this was the "PISA shock" of 2001, which immediately prompted debate on the importance and function of early childhood education in Germany. The result was that the country underwent an unprecedented shift, which we were able to observe while we were conducting collaborative research with our German colleagues (Fangmeyer \& Kašćák, 2016).

After 2001 a debate was launched in Germany on the schoolification of ECEC. 
The German case is interesting in that, compared to the UK, for example (see Moss, 2008; Clausen, 2015), ECEC has traditionally been an autonomous part of the social welfare sector and, moreover, is provided within a highly decentralised administration. Traditionally, there has been no engagement with the concept of schoolification, as can be seen in the preferred emphasis on formative processes besides just education (Bildung). This has usually meant upbringing (Erziehung) and care (Betreuung) (Frindte \& Mierendorff, 2017). ECEC has retained traditions and an identity that lie outside the school sector and its regional and therefore decentralised regulation reflects this tradition. The original focus on the child's social welfare and socialisation, rather than on preparing children for their future educational pathway, provided greater scope for autonomy in early years care and a means of avoiding the pressures of a homogenised global education policy. However, in the last twenty years this autonomy has waned as early childhood care has come under pressure from coordinated education policies.

In 2004 all 16 of the states that make up the Federal Republic of Germany agreed to adopt the first common framework document on ECEC - Gemeinsamer Rahmen der Länder für die frühe Bildung in Kindertageseinrichtungen (Ständige Konferenz der Kultusminister der Länder in der Bundesrepublik Deutschland, 2004). The document is discursively interesting in that the only institutions considered in it to be part of ECEC are the Bildung institutions. It therefore represents a break with the tradition that Bildung and Erziehung are inseparable (Frindte \& Mierendorff, 2017). The document also describes the skills children acquire as competencies in preschool institutions. It places special emphasis on how ECEC relates to primary education and general educability. Six recommended areas of Bildung are set out, which are to be reflected in the educational content provided by all ECEC institutions in the federal states. This was the first time that curricular coordination had existed between the federal states, and it was the beginning of the process of creating a new ECEC curriculum for each federal state.

Subsequent to this, curriculum development in the federal states underwent fundamental change. The new curriculum in each state emphasises developing children's language competencies and natural science and technical competencies (Gisbert, 2004). Schreiber (2009) showed in his analysis of three federal states that groups of teachers who had been deeply involved with the new curriculum focused greater attention on developing children's language competencies and mathematics and natural science competencies. Schreiber also found that an increasing number of parents would like to see stronger links between preschool institutions and schools and a smooth transition to primary school. One can argue that ECEC in Germany has entered a stage of strong schoolification. At the same time, we should note that consequently early childhood is undergoing a qualitative 
change in Germany. A process is ongoing whereby part of early childhood is increasingly being pushed outside the family, and early childhood is being both homogenised and politically optimised (Mierendorff, 2014).

\section{A return to the old - Slovakia}

Germany is an example of a country that had a developed tradition of preschool education that was confronted with the radically different idea of economising neoliberalism. We could say this was a between clash two different notions of ECEC in which the economising notion gained political and social legitimacy. Thus we have a change in the conception of ECEC.

Slovakia is another country with a long tradition of preschool education and that is a member of the EU. However, in Slovakia ECEC has traditionally been centralised, with a single national curriculum and public provision of preschool education, as is typical of most post-communist countries. Preschool education was not traditionally part of the social services sector and there was no notion of family-style preschooling. In the 1950s the network of preschool institutions became part of the school system, and later it would acquire the specific legal status of a "school facility". Hence one can argue that the schoolification of preschool institutions has been part of the long-term development of this sector in Slovakia.

There was a shift away from this tradition in the 1990s, following the fall of communism, during which the child once again became the focal point of preschool education and the strict centralist regime in preschools was rejected. This process led to the end of the single education pathway and to the familialisation of the institutional setting of the kindergarten, with greater attention being paid to respecting the needs of the child, rather than educational goals. In this era both kindergartens and the work of the teacher changed substantially; however, kindergartens still followed a central curriculum and the vast majority remained within the public sector.

However, in the first decade of the new millennium the new discourse of schoolification began to affect ECEC. Although the link between ECEC and primary education had always been strong in Slovakia, the two sectors had separate curricula. Serious efforts then began to ensure that curricular control was exerted over both levels of education by establishing similar principles for drafting curricula. These culminated in the passing of the 2008 education law, which stipulated similar principles for curricular planning and drafting.

In 2012 curricular coordination began via the introduction of similar teaching areas in both preschool and primary education. This process was completed in 2016. However, at the formal level the homogenisation of the two levels of education was rooted in the transition to a curriculum based around education standards. The education law adopted in 2008 triggered this process. In ECEC education, standards are 
mainly used in countries where efforts are made to objectivise and assess children's learning outcomes, especially in areas that correspond to the neoliberal view of ECEC as a social investment. They are not commonly found in continental Europe.

One might therefore have expected mass resistance amongst ECEC professionals to these untraditional elements. But instead they were, by and large, accepted positively (Kaščák, Pupala, \& Mbugua, 2016). Preschool teachers viewed the homogenisation processes as increasing and enhancing their professional status and therefore as processes that brought them closer to the status of their counterparts working further up the educational scale. As they worked with the education standards and curricular planning, the core of a new professional identity could be seen to emerge (Pupala, Kaščák, \& Tesar, 2016). It is an identity which is radically different to that of the widespread image of ECEC teachers as childminders. The positive acceptance of these changes can also be explained by the sudden changes associated with the 1990s that represented a radical departure from the well-established system. The subsequent re-homogenisation of preschool education through centrally set education standards that connected it to primary education struck a better balance between the two extremes of highly centralised preschool education on the one hand and the idealistic freer conception of childhood care on the other.

Arguably then, even radical changes to curricular conditions do not necessarily provoke upheaval, even in countries with a long tradition of preschool education. These are countries where there is a tradition of the schoolification of ECEC, where ECEC staff are accustomed to centralised control and where there is a desire for a higher professional status. In such contexts the neoliberalisation of ECEC may take place relatively smoothly and take advantage of previous developments in the sector.

\section{Globalisation of ECEC IN THE Global South}

The idea of promoting ECEC on a large scale has unquestionably also become a focal point in education policies in the countries of the Global South, also known as developing countries. In principle one can say that current support for ECEC in this part of the world is a response to the global political challenges and is a manifestation of the globalised nature of the education policy scene, despite such changes being localised and adapted to historical, cultural, and social traditions at the national level. We could document progress on this in the countries of the Global South using figures and tables from various international reports on the state of ECEC in different countries, produced by organisations such as UNICEF or the World Bank, or we could document it on the basis of national government reports or documents summarising the state of ECEC and its prospects in these countries. However, here we shall rely on a different source. Having had the 
opportunity to observe and experience ECEC whilst on related work trips to various developing countries, we were able to discover some of the less articulated aspects or multi-faceted reality of ECEC in operation. We shall base this section on the reality in the countries we have personal experience of, that is, Kenya in Afri$\mathrm{ca}$ and Nepal and Indonesia on the Asian continent. In each of these countries our work was related either to preparing development projects for preschool education or preschool work within academic circles with collaborative links to various forms of preschooling in a variety of settings.

As noted above, the promotion of ECEC is notable everywhere. Preschool education is now part of central government documents and part of the general discourse on education. The rhetoric is that preschool education determines a better life and improves children's life chances. The thinking on early childhood care and education is backed up by global lines of argument adopted primarily because doing so is a key condition to receiving the funding required to develop ECED in these countries, which mainly comes from the World Bank.

Perceptions of the rationale behind ECEC are therefore largely rooted in an imported model and discussion of early years education that, alongside the many attributes of the general support provided at the national level, is justified mainly in relation to the benefits it brings in relation to the country's economic prospects and prosperity. The greater focus on ECEC in these countries is then incorporated into central social and economic policies, into the regulation of ECEC provision and academic research and the drafting of study programmes for ECEC, and into the frameworks of central curricular policies. There is also a concurrent process of sensitising parents to the institutionalisation of ECEC as part of the foundations of the first step in a child's life path, which not only encourages parents to view institutional forms of childcare favourably, but also helps increase demand for differentiated preschool education according to parental status. The result is a gradual increase in the number of children in preschool institutions, growth in capacity, and a sort of convergence of missions in the development strategy of the given country.

\section{Parallel worlds - Indonesia}

"The Awakening of Indonesia's Golden Generation" is Indonesia's core strategic challenge, the central motive behind its education policy and its vision for 2045, in which its people represent a strong nation and thriving economy. It is one of the main slogans promoting early education that we encountered at a conference on preschool education entitled Building the golden generation (Batusangkar, October 2016). The idea behind it is for ECEC to become an important part of education generally, with early childhood representing the gateway to training a new successful and thriving generation. Training this golden generation involves paying careful attention to drafting and 
implementing the national preschool curriculum, which is primarily expected to be achieved through the development of "competencies".

We may have been particularly sensitive to what was probably a merely symbolic and metaphoric use of the phrase "golden generation" in Indonesia, because a few years ago we wrote our own book entitled Škola zlatých golierov [School of the Golden Collars] (Kašćák \& Pupala, 2012). The book is an analysis of the effects of neoliberal strategies on education policy, and the "gold-collar generation" is a good example of how the goals of education have coalesced around the image of the sought-after exemplary employee of a successful firm in the knowledge economy. At the central regulatory level, Indonesia is unambiguously projecting the preschool education sector around economic goals, and its golden generation, with the required competencies, as part of its plans to build the human capital for an economy that will thrive in the global competition.

Indonesia's central curriculum and goals reflect the ideas of Western global players in education policy, such as the aforementioned World Bank, OECD, and UNICEF, which are rooted in Western pedagogical philosophies and current Western (now global) education. The official public discourse on ECEC centres around these ideas, while on the periphery there is talk of the quality of ECEC, debated in normative academic terms, and this carries through into the creation and provision of academic teacher training for preschool teachers. The competencies of the future golden generation are the alpha and omega of university training courses for preschool teachers. They are a key theme in the professional development of existing teachers, and they are the ideology that informs the new preschool work methods.

Clearly, the influence of global education policy has led to the development of preschool education in Indonesia. It has brought investment stimuli and, in the spirit of neoliberalism, kick-started ECEC provision through private and community funding. The reality of preschool education as we experienced it in many preschools and in discussions with teachers or preschool heads, was, however, far more "Indonesian" than global. In the preschools and the work they do the global golden generation, with its Western image of successful living and a thriving society, was in fact rooted in domestic tradition and values, shifting preschool education away from universal Western imperatives and towards local life, with its culture and ideas about caring for and bringing up children. Preschools create their own educational setting that protects them against the direct colonisation of local models and traditions by the new ideologies, and keeps them within their own traditional cultural models.

This is immediately evident from a quick glance at the bullet-point summaries of the preschool education programmes that set out the mission underlying the pedagogic work, and which are usually to be found adorning the façades 
or hallways of buildings. The golden generation has been relegated to the back burner and is more an expression of the essence of Indonesian culture: (Islamic) religion underpins character, and is the essence of culture and security in life. Below is one example, but similar versions can be found in many preschools in different parts of the country:

\section{Nursery school mission:}

To ensure that the children have a balanced halal diet that provides stamina

To develop the children's potential in relation to their interests

To foster their faith and devotion to Allah SWT

To proffer good examples based on Islamic principles of teaching

To provide a stimulating environment for the growth and development of children in the family, at school, and throughout (translation of the mission of a nursery school in a village in Central Java)

Values such as these that are embedded in preschool education can also be found in rhetorical slogans, but teachers and directors also exhibit an awareness of them. When we talked to them and asked them to summarise in a single point what they considered to be most important in teaching children, they frequently stated that the point of their work was to guide the children into becoming good Muslims. They also said that this was a shared goal and an expectation of preschooling shared by the children's families and the communities they operate in. It seems that cultural roots and working for and in harmony with the community are more important than pursuing new goals and political and economic visions that call for school reform from afar.

However, we should point out that while it is possible for local alignment and a preschool education firmly rooted in local values to function reliably in homogeneous religious communities, in heterogeneous communities based on certain kinds of power relations they could lead to tensions and conflicts. As Adriany and Seafullah (2015) demonstrated, in Indonesia overall reliance on a community-led approach to fostering preschool education led to failures in implementing World Bank projects to improve preschool education in Indonesia. The allocation of funding in (targeted) communities raised both inter-community tensions (only some received the support) and intra-community ones (disagreements and tensions over decisions about resource use). The World Bank's intervention in Indonesia's education sector was based on the idea that the Western model of decentralised governance and rational decision-making works reliably in all societies; however, it did not generate the expected successes.

The attempt to reform preschool education in the Western image of an economically thriving golden generation came up against the traditional social structures of Indonesian society and also had to be filtered through traditional values. It is frequently the case that the preschooling provided in ordinary institutions frequently develops a life of its own 
that cannot be forced into simply adapting its mission so as to build the golden generation. The associated rhetoric is more figurative than a true representation of the reality of preschool education.

\section{In search of a mission - Nepal}

Nepal is one of the least developed countries of the Global South. Severely affected by natural disasters (earthquakes), it is a country rooted in Hinduism that has never been colonised and that was a monarchy until declared a republic with democratic elections in 2008. Perhaps because it never experienced the Western colonial model, the Nepalese education system began to develop very late on (compulsory three-year schooling was not introduced until 1975) and the first primary schools were set up in 1951 after the Nepalese government invited Jesuits from the West, who brought with them specific ideas about education and who continue to be active in Nepal today.

In Nepal as well, education (including preschooling) is seen as a path to a better life and a better future from both the national and individual perspectives. There is a dynamic and attractive education sector associated with individual prosperity. It also represents mainly a personal and specific investment in private education for the future of their children. It is a vision of a prosperous life; not in Nepal, but abroad - somewhere in the West.

There was therefore no need to import this model of education that is conceived of as a product, a commodity, and a per- sonal investment to raise a person's value on the global labour market via international organisations and large donor programmes; it developed naturally within Nepalese culture, particularly in urban locations. Some of the most visible advertising adorning the streets of towns or main roads in Nepal is adverts for education promising a great future. Preschools and higher education institutions are the most frequently advertised. The first ensure children get a good start on their educational pathway, while the second ensure exceptional work opportunities and a successful personal career.

Consequently, in urban areas preschool education has emerged as an important industry that appeals to betteroff families. Like everywhere else in the Global South, Western and well-established models of preschool education, especially Montessori nursery schools, are popular. The name (or brand) is what is important, not the programme itself, and English is also key and attracts customers. Montessori is such a strong brand that many young Nepalese people think it is a borrowed word meaning nursery school. The spontaneity with which urban preschool education is "regulated" as an urban education industry is reinforced by the fact that there is no specialist institution for training Nepalese preschool teachers. Teachers who work in Westernstyle preschools do receive specialist training. This is also true of those working in nursery schools set up by Western NGOs, but those who work in village community preschools or preschool classes have no 
professional training and have to rely on their own judgement and intuition.

Rural preschool classes and centres of preschool education emerge and operate differently. They are community-run centres created by and supported by the local authorities. They are set up and operate as part of government declarations and preschool support programmes in Nepal that bring together long-running efforts to strengthen child development, improve preschool success rates, and care for disadvantaged children and children at risk. These centres more or less follow their own paths and the rare reports on them that do exist tend to focus on fears over quality, as these preschools do not entirely conform to notions about the quality of preschool education.

However, it is important to note that existing and new preschool centres or classes in primary schools are basically a new phenomenon in rural Nepal and so they have no preschool tradition to follow. They can be compared against imported Western models or global criteria on the quality of preschool education, but of course they rarely correspond to these. The staff are unqualified and have no way of knowing about imported preschool education models. At most they can rely on short-term training courses, their own intuition, and their own conceptions of what their mission is. This could lead on the one hand to preschool education being limited to initial academic training courses for primary education (practising reading, writing, and arithmetic), while on the other hand it could pave the way for a more autonomous, Nepalese tradition of preschool education that is less dependent on the global imperatives that fail to take account of the local needs of the country and culture. Despite acknowledging the many serious problems with ECEC in Nepal, Upreta (2013), a Nepalese scholar, thinks a good beginning has been made and that it is heading in the right direction. The question remains as to which route Nepal will ultimately embark upon and whether it will satisfactorily be able to find its own path.

\section{Road to absorption - Kenya}

Kenya is a Sub-Saharan country on the coast of the Indian Ocean that has taken the lead in ECEC on the African continent. The first national preschool curriculum was introduced here (Kenya Institute of Education, 2008), with the support of the World Bank, and Kenyatta University in Nairobi launched the first early years education doctoral programme, Early Childhood Studies. As part of our development work, we performed a thorough analysis of early years education policy in Kenya and conducted empirical research on childhood and preschool education in one of the poorest areas of Kenya, in the coastal region of Kwale (for details on Kwale, see Arndt et al., 2016).

Preschool education has existed in Kenya since the colonial era; however, it was mainly aimed at British and Asian children. Immediately after the declaration of independence in 1963, this sector gained massive support. Nonetheless, it 
would not become truly institutionally regulated until after 1984, when central and regional bodies for preschool governance were established, such as the NACECE (National Centre for Early Childhood Education) in Nairobi and the DICECE (District Centre for Early Childhood Education) in the districts, set up with the support of the World Bank. Although from the outset the expansion of early years education stressed national principles, in the sense of the "Kenyanisation" of education (Mbugua, 2008), and the central underlying principle was the national philosophy of Harembee (lit. all pull together), the national education policy, including the preschool education policy, now fully reflects the universal globalising discourse, as we showed in our recent analysis (Mbugua et al., 2018), and education is now directed at the usual values of developing "human capital" for economic needs and the Western concept of wellbeing.

Kenya's strategic education policy documents clearly underline this, including the strategic materials relating to Kenya's new National Curriculum Policy (Ministry of Education, Science and Technology, 2015). A glance at this document shows that the global education agenda has been adopted in full. It states that the main goal in education must be to develop human capital, that it must be centred around a competency-based curriculum with clearly defined standards, be STEM-oriented (a curriculum based on the idea of educating students in four specific disciplines - science, technology, engineering, and mathematics - in an interdisciplinary and applied approach), and that it should be assessed using evidence-based outcomes and organised via private-public sector partnerships. Everything that is carried out in the name of global educational goals is justified by the fact that: "The fast-paced growth of the global economy requires competitive youths with relevant work skills that match the growing economy" (p. 8).

A peculiar mix of educational culture is emerging as a result of the pressures of globalisation, as we observed in preschool institutions in the region of Kwale. In a traditional local setting, where preschool teacher training was provided, we found, for example, that the décor contained symbols of Western company culture that were intended to foster a feeling of excellence, encourage a Western work culture, and promote competitiveness and performance. There was no room here for local symbols or local culture; these were already disappearing from national documents, and there was increasingly less space for them in the local curriculum and traditions. Preschools in the regions are run on very limited financial resources and have difficulty fulfilling the conceptions of a modern education. Teachers suggested that they were criticised by the centre for not pursuing global and central challenges sufficiently. A gulf is emerging between those who insist on and set a central education policy and what is provided to these preschools, which have to survive on restricted local resources. 
On the one hand, there is evidence in Kenya of what is perceived in postcolonial theories to be the persistence of colonisation (Gupta, 2006), and there are indications that Kenya has resigned itself to a strategy whereby preschool education is incorporated into the various needs and potential of the local community. On the other hand community preschools are left with no choice other than to restrict themselves to using their own resources and making the best of their possibilities, adapting preschool education to their own needs. In the background motivation may be found in resources and ideas that defend culturally appropriate teaching (Gay, 2000) and which emphasise the relevance of education to the social and cultural milieu. There is often reference to this in preschools in Kenya, particularly regarding teaching materials, and there are recommendations on how teachers can create resources out of what is available locally. However, the question is whether in this case the recommendations on cultural relevance are not merely a means of accounting for the lack of resources being invested in preschool education.

\section{Conclusions}

The global transformation of ECEC is clearly much in evidence. One can argue that this transformation is being driven by the notion that early years education should be harnessed to economic wellbeing at both the societal and individual levels. The global perception of ECEC as a generator of economic and human capi- tal informs education policy in both the Global North and the Global South. As we saw in Germany's case, even in developed countries, this transformation may clash with a historical ECEC identity and lead to the reconstruction of the entire sector. It is not therefore just developing countries that find themselves being colonialised by conceptual pressures.

The change in perception of ECEC at the European Union level, from a concern with the rights of the child to a social investment agenda, has put pressure on EU countries in which a significant part of ECEC has traditionally been more careoriented, with family-style relations in groups of children and a loose relationship with the school. Alongside Germany, other countries to find themselves under pressure are the Scandinavian countries, and there are few indications to suggest that they will be able to resist either (Paananen, Lipponen, \& Kumpulainen, 2015). Nonetheless, this process is not as dynamic or as direct as it is in the new EU countries.

The new EU countries represent a special case because of their communist pasts. Under communism ECEC was centrally managed and controlled via a detailed curriculum, teachers' responsibilities were clearly set out, and ECEC was closely tied to compulsory schooling. These countries appear to have absorbed the neoliberal pressures of education policy more easily and have even come up with steps for how to implement these ideas. The new measures on coordinated curricular control and increasing schoolification are similar 
to the techniques of governance used historically in these countries. Consequently, far fewer questions are asked, even by those working in the sector.

The situation is more varied in the Global South. In all three countries mentioned above there is strong political pressure to economise and neoliberalise the ECEC sector. However, most of these countries have no historically developed concept of institutionally-based ECEC to rely upon. They have found it very difficult to create an arena in which a productive discussion on alternative ways of organising ECEC could emerge. Historically, they have been reliant on imported models of education policy, either because of their colonial pasts or because of the role played by supranational organisations. Since small children in these countries often live in difficult circumstances, one would expect there to be greater pressure to ensure that the basic needs of these children are met, that is, that the emphasis within ECEC would be on care and on ensuring that the approach to organised ECEC would protect the rights of the child. Our experience shows, however, that this dimension is rarely mentioned in strategic ECEC documents. Some kind of competitive economic arena is emerging, similar to that in the countries of the Global North. The curricula in Indonesia and Kenya are evidence of this.

Nonetheless, the effect of these curricular policies on the lives of the children, teachers, or even preschool institutions is varied. Whilst in Indonesia there are parallel worlds of policy and practice, which may in itself be seen as an example of a kind of non-conflictual, peaceful coexistence between the two worlds, in Kenya the gulf between curricular policy and everyday practice is causing tension. The gap between the globalist declarations of the centre and the reality in the preschools operating in the poorer areas of Kenya is so large that local ECEC administrators and teachers are worried that they are not in fact capable of fulfilling this vision. This lies in direct contrast to what we described of our Indonesian experiences. There we could see that the distant visions of globalised political rhetoric can be, and are, compensated for by local visions of ECEC provision that are rooted in the activities of these preschools and the teachers working within them. Thus these two different countries in the Global South have responded in distinct ways to the same globalising pressures now incorporated into their central ECEC policies, and where there is some distance between central policy and the specific national and local conditions. Nepal lies somewhere between these two models, and its development will be particularly interesting to observe. It is a country that has no history of colonialism or of institutionalised ECEC. The market preceded state regulation, and there are no firmly defined ECEC intentions and goals. The two preceding cases are both relevant to Nepal. However, there is a third, more cautious strategy that has by all accounts been adopted in Bhutan (Sims \& Pedey, 2015). There the tension between the universal economising imperative and the 
ECEC sector has been compensated for at the central level through a mixture of these imperatives and Buddhist values, which not only enables the traditional cultural values to endure within the national ECEC but also means teachers and preschools can legitimately rely on their existing cultural identity and mission.

We therefore argue that Moss's (2009) well-known slogan "there are alternatives!" does not just apply to resistance to the neoliberal pressure to transform ECEC. While we cannot find any such examples of resistance at the level of national education policy, we can see islands of positive deviation, even in countries of the Global North that have to some extent accepted certain elements of economisation. Moss's slogan holds true at the point where policy and practice meet, and at the point where teachers become actors within the institutions of ECEC (Millei, Gobby, \& Gallagher, 2017). It is here that the opportunity for engagement may emerge.

\section{ACKNOWLEDgement}

This study was supported by the VEGA agency under grants 2/0134/18 and $1 / 0258 / 18$ and the KEGA agency under grant 009TTU-4/2018.

\section{REFERENCES}

Adriany, V., \& Saefullah, K. (2015). Deconstructing human capital discourse in early childhood education in Indonesia. In T. Lightfoot-Rueda \& R. L. Peach (Eds.), Global perspectives on human capital in early childhood education. Critical cultural studies of childhood (pp. 159-179). New York: Palgrave Macmillan.

Arndt. S., Tesar, M., Pupala, B., Kaščák, O., \& Mbugua, T. (2016). Re-Negotiating an ethics of care in Kenyan childhoods. Human Affairs, 26(3), 288-303.

Casalini, B. (2014). The Early Childhood Education and Care Policy debate in the EU. Interdisciplinary Journal of Family Studies, 19(1), 77-94.

Clausen, S. B. (2015). Schoolification or early years democracy? A cross-curricular perspective from Denmark and England. Contemporary Issues in Early Childhood, 16(4), 355-373.

European Commission. (2011). Early childhood education and care: Providing all our children with the best start for the world of tomorrow. Brussels: European Commission.

Fangmeyer, A., \& Kašč́a, O. (2016). Transgressionen: Zum diskursiven Rekonfigurieren von institutionalisierten (frühen) Kindheiten. Ein slowakischdeutscher Vergleich von curricularen Dokumenten. In I. Nentwig-Gesemann, K. Fröhlich-Gildhoff, T. Betz, \& S. Viernickel (Eds.), Forschung in der Frühpädagogik 9 (pp. 141-172). Freiburg: FEL.

Frindte, A., \& Mierendorff, J. (2017). Bildung, Erziehung [education] and care in German early childhood settings - spotlights on current discourses. Journal of Pedagogy, 8(1), 99-120.

Gay, G. (2000). Culturally responsive teaching: Theory, research and practice. New York: Teachers College Press. 
Gisbert, K. (2004). Neue Bildungsinhalte. In I. Wehrmann (Ed.), Kindergärten und ihre Zukunft (pp. 138-148). Weinheim: Beltz.

Gupta, A. (2006). Early childhood education, postcolonial theory, and teaching practices in India: Balancing Vygotsky and the Veda. New York: Palgrave Macmillan US.

Jones, P. (2010). The politics of the economics of education in the European Union. European Educational Research Journal, 9(3), 359-380.

Kašćák, O., \& Pupala, B. (2012). Škola zlatých golierov: Vzdelávanie vére neoliberalizmu [Golden Collar School: Education in the Era of Neoliberalism]. Prague: SLON.

Kašćák, O., Pupala, B., \& Mbugua, T. J. (2016). Slovak preschool curriculum reform and teachers' emotions: An analysis of Facebook posts. Early Childhood Education Journal, 44(6), 573-580.

Kenya Institute of Education. (2008). Handbook for Early Childhood Development Education Syllabus. Nairobi: Kenya Institute of Education.

Khanal, S.K., Paudyal, B.R., \& Dangal, S. (2017). Early childhood development policies in Nepal: Achievements, learning, and implications. In H. Li, E. Park, \& J. Chen (Eds.), Early Childhood Education Policies in Asia Pacific. Education in the Asia-Pacific Region: Issues, Concerns and Prospects, vol. 35 (pp. 135-161). Singapore: Springer.

Mbugua, T. (2004). Early childhood care and education in Kenya. Childhood Education, 80(4), 191-197.

Mbugua, T., Pupala, B., Kascak, O., \& Petrova, Z. (2018). Transforming Public education in Kenya: Early childhood development and education in Kwale County. In C. S. Sunal \& K. Mutual (Eds.), Transforming public education in Africa, the Caribbean, and the Middle East (pp. 53-71). Charlotte, North Carolina: Information Age Publishing.

Mierendorff, J. (2014). Annäherungen von Kindergarten und Schule. Wandel früher Kindheit? In P. Cloos, K. Hauenschild, I. Pieper, \& M. Baader (Eds.), Elementarund Primarpädagogik. Internationale Diskurse im Spannungsfeld von Institutionen und Ausbildungskonzepten (pp. 23-37). Wiesbaden: Springer.

Millei, Z., Gobby, B., \& Gallagher, J. (2017). Doing state policy at preschool: An autoethnographic tale of universal access to ECEC in Australia. Journal of Pedagogy, 8(1), 33-55.

Ministry of Education, Science and Technology. (2015). National curriculum policy. Nairobi: Ministry of Education, Science and Technology.

Moss, P. (2008). what future for the relationship between early childhood education and care and compulsory schooling? Research in Comparative and International Education, 3(3), 224-234.

Moss, P. (2009). There are alternatives! Markets and democratic experimentalism in early childhood education and care. Working papers No. 53. Hague: Bernard van Leer Foundation.

Nicaise, I., \& Schepers, W. (2013). Social investment: the new paradigm of EU social policy? Belgisch Tijdschrift voor Sociale Zekerheid, 55(2), 189-230. 
Paananen, M., Lipponen, L., \& Kumpulainen, K. (2015). Hybridisation or ousterisation? The case of local accountability policy in Finnish early childhood education. European Educational Research Journal, 14(5), 395-417.

Pupala, B., Kaščák, O. \& Tesar, M. (2016). Learning how to do up buttons: Professionalism, teacher identity and bureaucratic subjectivities in early years settings. Policy Futures in Education, 14(6), 655-665.

Schreiber, N. (2009). Die Einführung der neuen Bildungspläne in Kindertageseinrichtungen - Ergebnisse von Begleitstudien in drei Bundesländern. Diskurs Kindheits- und Jugendforschung, 4(3), 431-437.

Sims, M., \& Pedey, K. (2015). Are we travelling a similar path to early childhood professionalization? The case of Bhutan. International Journal of Innovation and Research in Educational Sciences, 2(3), 218-226.

Ständige Konferenz der Kultusminister der Länder in der Bundesrepublik Deutschland. (2004). Gemeinsamer Rahmen der Länder für die frühe Bildung in Kindertageseinrichtungen. Bonn/Berlin: KMK.

Upreti, N. (2013). National plan and policies for early childhood education and care in Nepal. Child Research Net. Section: Asia, ECEC around the World, Reports from around the World. Retrieved from www.childresearch.net/projects/ecec/2013_05.html

\section{Branislav Pupala}

Department of School Education, Faculty of Education, Trnava University, and National Institute for Education, Bratislava, Slovak Republic;

e-mail:bpupala@truni.sk

\section{Ondrej Kašćák}

Department of School Education, Faculty of Education, Trnava University, Slovak Republic, and Department of Education, Faculty of Arts, Charles University, Czech Republic

\section{PUPALA. B., KAŠČÁK, O. Od Juhu na Sever v globalizovanom svete starostlivosti a vzdelávania $\mathrm{v}$ ranom detstve: Diverzita národných a lokálnych reakcií vo vybraných krajinách}

Štúdia analyzuje procesy neoliberálnej transformácie sektoru starostlivosti a vzdelávania v ranom detstve (VSRD) v piatich vybraných krajinách (Nemecko, Slovensko, Indonézia, Nepál a Keña). Ide tak o krajiny globálneho Severu ako aj krajiny globálneho Juhu. 
Uvedené krajiny sú vybrané na základe výskumnej angažovanosti autorov v nich resp. na základe dlhodobých osobných skúseností s uvedenými systémami VSRD. Nadobudnuté poznanie umožňuje hlbšie preniknút do detailov stretu daných systémov VSRD s neoliberálnymi vzdelávacimi politikami a opisat diferencie v procesoch adaptácie daných krajin na nové politiky. Štúdia ukazuje, že neoliberálne vzdelávacie politiky implikujú rôzne typy adaptačných reakcii a že dopady na sektor VSRD môžu byt velmi rozdielne - od výmeny konceptov, systémovej konvergencie, praktickej rezistencie až po úplné ovládnutie sektoru. Študia tak prispieva k diferencovanejšiemu chápaniu pôsobenia ekonomizovaného diskurzu na národné systémyVSRD.

Klúičové slová: vzdelávanie a starostlivost'v ranom detstve, sociálno-investičný prístup, Európska únia, Nemecko, Slovensko, Indonézia, Keña, Nepál, globálny Sever, globálny Juh 